\title{
The Emerging Roles of Coaches in the Malaysian Dual Training System
}

\author{
Ahmad Othman \\ Faculty of Manufacturing Engineering and Technology Management \\ Universiti Malaysia Pahang \\ Lebuhraya Tun Razak, 26300 Kuantan, Pahang, Malaysia \\ Tel: 60-7-453-8093Ｅ-mail: ahmadbo@ump.edu.my
}

Nor Hazana Abdullah

Faculty of Technology Management

Universiti Tun Hussein Onn Malaysia

86400 Batu Pahat, Johor, Malaysia

Tel: 60-7-453-8093 E-mail: @uthm.edu.my

Mohamad Sulaiman

Department of Skills Development

Ministry of Human Resources Malaysia

Pusat Pentadbiran Kerajaan Persekutuan

62502 Putrajaya, Malaysia

Tel: 60-7-453-8093 E-mail: @uthm.edu.my

Alina Shamsuddin

Faculty of Technology Management

Universiti Tun Hussein Onn Malaysia

86400 Batu Pahat, Johor, Malaysia

Tel: 60-7-453-8093 E-mail: @uthm.edu.my

This research was supported under the Fundamental Research Grant Vote 0421.

\begin{abstract}
This paper discusses the new task of industry personnel as coaches in the National Dual Training System (NDTS), a newly introduced training initiative for producing k-workers in Malaysia. The decision to introduce this initiative was made by the Malaysian Cabinet on the 19th May 2004 with the hope that it will resolve the issue of skilled workers being produced, but not meeting the needs of the industry. The initiative began in 2005 for four skill sets, i.e., manufacturing tools (tool and dies), automatic control process, automotive mechanics and plant operations. In this new system, the industry plays an important role to ensure 70 percent of the training is carried out at the workplace and the rest 30 percent of the training will be carried out at the training institution premises. After completion of the four semester program, apprentices are awarded the NDTS k-Worker Certificate. Since the industry personnel plays a greater role than before through the newly introduced system, the understanding of new tasks of industry personnel as coaches to the apprentices is explored. The analysis of literature shows that different levels of personnel, i.e., executive, supervisory and senior technician require different skill sets in carrying out the coaching tasks. Based on this requirement, therefore, the potential enhancement programs required to equip these personnel with necessary skills can be developed.
\end{abstract}

Keywords: Skills training, Training management, Trainer of training

\section{Introduction}

In its vision to become a developed nation by the year 2020 Malaysian leadership has stressed that the nation "should not be developed in the economic sense. It must be a nation that is fully developed along all dimensions: economically, politically, socially, spiritually, psychologically and culturally" (Malaysia, 1991a). Harbison and 
Myers (1964) postulated that the economic, social, cultural and political growth can be achieved as a result of human effort, and the initiative of developing human resource will unlock the door for modernization. Realizing the importance of developing human resources towards achieving the Malaysia's Vision 2020, the Second Industrial Master Plan, 1996-2005 has focused on HRD as one of the critical elements that would underpin Malaysia's strategic vision of attaining 'developed' status (Malaysia, 1991a). Accordingly, Harbison and Myers (1964) suggested that if one of the major goals is rapid economic growth, then programs of human resource development must be designed to provide the knowledge, the skills and the incentives required by a productive economy. Woodhall (1971) supported their views by arguing that a country's economic prosperity depends not only on the supply of natural resources and the amount and utilization of physical capital, but on the education, training and productive skills of its workers.

In many countries, especially developing countries, the responsibility of developing human capital has rested heavily on the government. This is particularly true in the case of Malaysia where there is an increasing number of public training institutions in almost every five-year development plan (Othman and Morgan, 1998; Malaysia, 2001, 2006). This is obviously a major initiative to increase the output of skilled manpower to meet the needs of the economy. In this situation, the industry has to accept the quality and level of experience gained through the public delivery system. However, history has shown that industry cannot and should not rely solely on the Government initiatives, neither in the aspect of capital investment nor in the aspect of human investment since human resource development is a long-term initiative, as is the case in all major industrialized countries (Othman, 2009). Employer, being a major consumer of skilled workforce, therefore has to take a fair share of responsibility in the development of skilled workforce, particularly in specific and highly skilled areas (Othman, 2003, 2005). The skilled workforce developed through this program will gain competitive advantages. This applies to all levels of personnel hierarchy, ranging from managerial to the production levels. Hence, new methods and strategies in delivery must be developed, accepted and implemented efficiently (Mohamed and Othman, 2006).

Industrial training nowadays is cost-intensive, both capital and operational. Costs of programs beyond the pre-vocational level are high and are getting prohibitive for public agencies (Pillai, 1992). New thinking and directions are necessary to further define the role of public agencies and industries, especially in technology-intensive and heavy industries. It has also been recognized that the private sector and enterprises are best placed to identify the training needs for skill upgrading and retraining. They can also identify the technology being used in industry as well as acquire expertise in the usage of that technology directly from vendors. To encourage the private sector to play a more effective role, the followings are recommended by the Cabinet Committee on Training: (i) increasing collaboration with the private sector; (ii) improving incentives for training; and (iii) establishing specialist training centers (Malaysia, 1991b).

The rest of the paper is organized as follows; Section 2 presents The German Dual System: A Model for Malaysia. Section 3 discusses The Malaysian Skills Training System Revisited. Section 4 discusses New Tasks for Industry Personnel as Coaches in the implementation of NDTS in Malaysia. Finally, the conclusions of our work are described in Section 5.

\section{The German Dual System: A Model for Malaysia}

In Germany, the dual system training has been implemented long ago with very strong support by industries (Deissinger, 1997, 2001). The German dual system has its roots in the corporatist framework established by legal sanction in the late nineteenth centuries that not only remained virtually unchanged in its basic features up to the establishment of the Vocational Training Act in 1969, but was incorporated into the modern training system (Deissinger and Hellwig, 2005). As Schmidt and Alex (1997) explained, "the dual system is founded on close links between public and private training organizations, between statutory provision and provision governed by collective agreements, and between public training policy and private training investment." They also listed significant characteristics that made the German's Dual System being recognized and thus supported by German industries as follows: (i) participation of companies is voluntary, (ii) standards and content of training are agreed by employers and trade unions and then legally codified, (iii) cooperation between employers and trade unions at various levels supports and renews the system, (iv) independence of the system is preserved through corporate bodies (chambers), (v) the system is financed mainly by corporate training providers with supplementary funding coming from government, and (vi) the provision of further education includes both general and occupation-related theoretical study.

Schmidt and Alex (1997) also argued that the success of the German's Dual System are mainly due to vocational qualifications earn high standing in Germany; skilled blue- and white-collar workers and SME craftsmen enjoy a high status in society; VET is a primary political concern; the Dual System is not questioned by any major political party as the most suitable system of VET likewise both employers and trade unions regard it as the stable basis of their VET policy relationship; large research and development institutes offer database and advice to employers, 
trade unions and the government, and they provide a platform for joint planning and for the improvement and adaptation of vocational training; when planning VET, the government acts on the consensus principle by building on the agreement of employers and trade unions and employers and trade unions provide on-going renewal of the training content and the examination syllabus.

In short, one of the traits that distinguish the German dual system of vocational education and training (VET) from most training systems in the world is the voluntary contribution of companies towards the system, in both operations and financial terms. Obviously in the craft sector, the importance of practical experience is strongly emphasized than the systematic approach underlying all modern training schemes. This means that training is workplace-led and it implies that the system actually works in accordance with skill requirements defined around the workplace (Deissinger, 2001). Such effort requires a reliable organizational framework and also major participation of firms beyond imparting the skills needed for a specific job. However, the importance of enterprise's responsibility has not led to over-specialized training as the priority has always been towards broad-based knowledge and the acquisition of basic techniques. For this purpose, the administrative and organizational contribution of the industries or enterprises seems crucial and virtually indispensable. Although the apprenticeship itself is the responsibility of employers and trade unions, quality control is linked to public interest in preventing the qualification process from being unrestrictedly exposed to market forces.

\section{The Malaysian Skills Training System Revisited}

The changes in technology globally, and particularly in the Malaysia's industries, have created a dire need for skilled workforce as well as a comprehensive skills training system. Thus, on 19th May 2004, the Malaysian government has approved the implementation of the National Dual Training System (NDTS), a newly introduced training initiative for producing k-workers in the country. With this initiative, it is hoped that it will resolve the issue of skilled workers being produced but not meeting the needs of industry. The main purpose of the NDTS is to stimulate and assist industry in developing and improving apprenticeship system and other training programs designed to produce the skilled workers needed to compete in a global economy. The implementation of NDTS involves two "learning venues": (i) the company providing on-the-job training (the actual apprenticeship) and (ii) off-the-job training where the apprentice receives theoretical instruction. Employers and labour groups as well as employer associations jointly sponsor the NDTS programmes. The initiative starts in 2005 for four skill sets: (i) manufacturing tools (tool and dies), (ii) automatic control process, (iii) automotive mechanics, and (iv) plant operations.

In this new system, the industry plays an important role to ensure 70 percent of the training is carried out at the workplace. The rest 30 percent of the training will be carried out at the training institution premises. Under this initiative, trainers at the workplace play a vital role to impart psychomotor skills to apprentices. In contrast, the trainers at the training institution will be dealing with theoretical classes and very little on practical works. The types of training program under the NDTS will be determined by the industries concerned in collaboration with the training institutes, whether it is to be day-released or block-released whichever is convenient to the industries. In the day-released program, the apprentices are trained at the industry for four to five days a week and the remaining one to two days at the training institutes. In the block-released program, apprentices undergo training for four to five months at the industries and one to two months at the training institutes. The training period is about two years with four semesters.

In the company the apprentice receives practical instructions at his or her workplace regarding the work process. The training follows mainly the principle of "learning by doing" with short instructions from the responsible coach or trainer. In small and medium-size enterprises (SMEs) the instructions are given by the foreman or other technical personnel of the department, whilst in larger companies the training are normally handled by special training staff. The practical training allows the smooth transition from training to working life. The detailed course of training is specified in the appropriate training guides to ensure that training is conducted to a uniform standards set with the collaboration of the respective industries. However, the implementation of NDTS does not work without problems and generally the problems are similar among firms. One of the main problems faced by industry is the trainer and the problem related to trainer is the language used for teaching and learning (T\&L). Many industries especially SMEs, their experienced foremen and supervisors are generally with secondary school level qualification. In-house training by supervisors or managers is often hampered by the lack of their teaching abilities coupled with communication problems. The new role for language competencies in transformed work situation is related to the decrease in manual operations on products or objects and the increase in the use of signs, codes and symbols in the workplace.

In the implementation of NDTS, trainer is the key player at both training places whether at workplaces or training institutions. At the training institutions, the trainer acts as instructor to impart technical theory such as the usage of machine and hand tools, and non-technical subjects such as mathematics, sciences, and safety. Also, the trainer has to coordinate and manage apprentices to ensure that all training activities meet the training institute requirements. At the workplace, technical personnel such as foreman, supervisors or executives of the enterprises that involve in the 
training activities are recognized as coaches and not trainers. The coach's role is to train apprentices on the actual technical aspects of work processes. At the same time they need to carry out their core duties as supervisors or executives or senior technicians at the enterprises where they work. Can the industry personnel such as supervisors or executives or senior technicians be functioning effectively as coaches in implementing NDTS at the workplace environment? What are the factors that contribute to the effectiveness of the coaches in the delivery of the training at workplace?

As coaches, the executives or supervisors or skill technicians need to equip themselves with the teaching skills, social skills, management skills as well as the latest technical skills required by the current technology. In this case, they must be prepared to carry out extra functions and duties as their employer plays an important role to ensure $70 \%$ of the training carried out at the workplace is successful. This paper will therefore investigate the significant tasks for coaches in order to carry out their responsibility under the NDTS program effectively.

\section{New Tasks for Industry Personnel as Coaches in the implementation of NDTS in Malaysia}

The implementation of NDTS in Malaysia involves industry personnel who are appointed as coaches and this may be successful if they are exposed and trained to acquire the techniques of instruction and teaching/learning social skills (Gibbons-Wood and Lange, 2000; Rahim and Khadijah, 2010). This new system requires three categories of personnel to carry out training program at the workplace, i.e., executives, supervisors and senior technicians or senior skilled workers. Sulaiman (2010), in his study, has identified a set of tasks that these various categories of personnel are expected to deal with in implementing NDTS, i.e., the executives will be dealing with the planning and management of training, the supervisors are required to monitor and supervise the training delivery, and the senior technicians are required to carry out training in the form of facilitating, demonstrating, counseling and assessing apprentices' performance. In terms of technical capabilities and qualification, there are obviously differences between the three categories of personnel. For instance, on the aspect of qualification in term of process knowledge, the executives are high as compared with the others. Likewise, on the aspect of the experienced-based technological knowledge, the senior technicians are high as compared with the others. In terms of attitude, the executive level has high commitment on continuous learning compared with lower rank personnel. The potential challenges that are faced by the industry personnel in carrying out these new tasks can be seen in Table 1 .

$<<$ INSERT TABLE $1>>$

In conclusion, in order for the industry personnel to be functioning as coaches, they have to be equipped with theoretical knowledge and experienced-based knowledge requirement. The potential programs needed by the industry personnel are as shown in Table 2 .

$<<$ INSERT TABLE 2>>

The new tasks faced by staff that involve in initial and continuing training can be predicted in the context of changing company's skills requirements due to the acquisition of new technologies, orientation to customer needs as well as the improvement processes of business. There is a considerable increase on the demands made on staff training as a result of technological development as well as and the changing conditions and interests on the part of learners. The person responsible for the instruction is responsible for the entire process. The roles of the trainers are changing and they have to play other roles as well which include among others, as: (i) strategic planner, (ii) training manager, (iii) analyst to carry out training needs analysis, (iv) training program designer, (v) training material writer, (vi) training implementer, (vii) facilitator, (viii) counselor, (ix) multimedia expert, and (x) training evaluator.

The industry coaches and other skilled workers involved in the initial and continuing training play a key role in initiating and designing new forms of learning and realizing new learning concepts. The forms of learning described above, i.e., self-organized and lifelong learning, and the integration of experiential and deliberate learning are topical and important examples of these new tasks. The competent coaches must equip themselves with knowledge and skills in order for them to function effectively. The coaches must acquire and be trained in some specific skills and knowledge in order for them to be effective and competent, that are understanding on adult learning; skills in career and counseling; facilitation skills; skills on delegation and empowerment; skills on negotiation and interpersonal relation; skills in lecturing; and understanding on organization behavior.

Hence, the coach must be a professional and must have four main criteria that are vision, competence, work ethics or professionalism, and identity (Mamat, 2001). According to Gerds and Hoepfner (2003), the TVET trainers must be able to have such requirement as follows: (i) provide a narrow linkage between their own pre-service (initial) and in-service (further) teacher training, and to use modern ways of distance and e-learning; (ii) have command of the vocational (practical) skills and theoretical knowledge they have to train their students; (iii) establish and conduct strong relationships and networks between their schools and the local/regional business in order to offer vocational training on needed and employable qualifications; (iv) develop demand-driven contents and forms (courses, 
programs, modules) of TVET programs; and (v) recognize the large variety of student's demands, interests and prerequisites of learning.

\section{What are the requisite required by the coaches in carrying out of the new tasks?}

The report of the project of Professionalization of VET Teachers for the Future (PROFF) has listed some of the skills and knowledge needed to be acquired which include: (i) new pedagogical skills in line with the learner-centered approach of modern pedagogical theory and on-the-job learning techniques; (ii) up-to-date vocational skills related to modern technologies and work practices; (iii) awareness of the needs of business and employers; (iv) skills for team working and networking; and (v) management, organization and communications skills (Cort, et al., 2004).

The National Project Team (NPT) of the program of the European Union has clarified that the teachers or trainers need to possess the confidence, skills and qualities required to create and manage learning in environments most appropriate to the needs of their learners. In particular, they will be: (i) leaders of learning and life-long learners, (ii) facilitators of learning teams, (iii) leaders of innovation in schools and society, (iv) flexible and adaptable, (v) innovative, enterprising and positively welcome change, (vi) responsive to the needs of students, colleagues and the community, (vii) cooperative with colleagues and students, and (viii) acquire a more holistic way of knowing.

Therefore the coaches or trainers are responsible for facilitating the on-going process, creating the environment that best helps the apprentices reach their defined goals. According to NPT, the coaches or trainers' roles are to facilitate the process by being instructor, initiator, aspirator, partner, mediator, counselor, or coordinator. The coach at the workplace is the key personnel to turn to in the implementation of dual training system so that the apprentices understand the concept of dual training system; prepare the training structure; orientates the apprentices on the introduction to dual training system and responsibilities of apprentices and coaches; guides, mentors and evaluates apprentice's performance throughout their training; executes training based on training standard; checks, endorses and verifies the log book entries; and prepares the final evaluation of the apprentice.

\section{Limitation}

Large companies often have developed good practice in training and have the resources to employ full-time, well qualified trainers as coaches. They operate their own training centres and develop their own training materials and methods. Small and medium-scaled enterprises (SME), however, do not have these luxuries. As pointed by Sulaiman (2010), they are facing lack of resources due to staff shortages, lack of knowledge and know-how when it comes to training, lack of young motivated trainers and lack of time for training. SMEs can only offer basic training if they cooperate with other companies and would largely benefit from inter-company cooperation in the area of training, training of trainers and exchange with large or multinational companies.

Also, enterprise boundaries are becoming blurred and the concept of the traditional pattern of training where the stress is on open training markets is challenged. Acceptance by industry towards participating in the scheme needs serious consideration. The changing work environment because of the implementation of NDTS leads to modifications in job content of industry personnel, skills requirements and the demand for new knowledge among those involved. The qualifications of coaches from rather different training backgrounds: the personnel assigned as coaches are recruited mostly from rank-in file and not as in the case of teachers of vocational training institution where they are recruited from among college graduates.

\section{Conclusion and Recommendation}

The changes in technology combined with the demographic, occupational and workplace changes have had a significant impact on the nature of the workplace itself. While most will agree that the changing workplace requires ever-changing skills and knowledge, not everyone agrees on the best approach to meeting the challenge. The older notion of training where trainees be trained at a training center away from workplace, is still prevalent today. While training still has its place, it can no longer be viewed as just occurring in classes and workshops and, most will agree that it is insufficient especially in inculcating actual work experiences. A new and broader view of the learning process at work is needed. These changes have meant that the skill level of employees at all levels (managerial, supervisory and technical) must be continuously cultivated and developed in order to keep up with the demands of today's business. This is particularly important in a situation where the employees wear two different hats, as regular employee and as coach under the NDTS program.

Besides the main responsibilities that the employees have to carry out (as regular employees), under the NDTS program those involved (as coaches) also have to have other capabilities such as: the pedagogical skills, technical skills (experienced-based), technical theoretical knowledge, communication skills, knowledge on curriculum development, management of training activities, training evaluation and assessment, ICT skills, facilitation skills, language competencies, and diagnostic competence. 
There is no doubt that under the NDTS program, the learning process does not depend solely on the trainer or coach since learning is a social construct and learning occurs in groups of co-workers as they construct and reconstruct knowledge, skills, and abilities. Thus, working and learning go hand-in-hand as totally complementary activities. In fact, whether an activity is called "working" or not, it generates experiences - and experiences are the staple diets of learning. Working is learning and learning happens at and through working. Once this is understood, the next important step is to create a working environment that is conducive to learning.

In order to ensure that the NDTS in Malaysia will be successfully implemented, several recommendations are put forward for consideration. Firstly, there are hardly any statistical data are being generated on trainers, which could specify their socio-economic characteristics such as employment status, social background, educational level, skills qualifications, age or gender. The main reason why statistical data on trainers are not being generated is because trainers are not recognised as a distinct category, neither in terms of their function nor as an occupational group. Even full-time trainers may not be recognised as a particular employee category by legislation or the company. Lack of background information and data makes it extremely difficult to assess the situation, status and qualification of trainers and plan and predict future developments and needs in the area of training and trainers. Thus, more research and data generation on trainers should be promoted, encouraged and supported at the regional and national levels.

Secondly, due to current situation where the qualified NDTS coaches are scarce, it is advisable to make some improvement on the existing TVET-Teacher training programmes. In this regards we need to strengthen the collaboration and partnership between different institutions responsible for training of trainers. We should bring various stakeholders of training together and facilitate cooperation, partnership and networking between them to make vocational training programmes more effective and strengthen the trainers' role, cooperation between vocational schools, enterprises and public administration in the implementation of training and the training of trainers and also foster stronger exchange between different stakeholders and research institutes.

Thirdly, the Centre for Instructor and Advanced Skill Training (CIAST) is offering pedagogical training course and advanced skills training for future and in-service instructors including the industry personnel such as technician and supervisors. In this regards, certain basic requirements to become a coach should be considered, such as the imposition of minimum qualification of at least the Malaysia Skills Certificate (MSC)/SKM Level 3. Also, the additional component should be added to the existing curriculum, such as the English language course and engineering theoretical subjects. Another suggestion is to hire or engage expert trainers from industries as part-time master trainers at the CIAST. This is due to the urgent need by the Centre where they do not have sufficient number of expert trainers especially in the area of rapid technological change. Industrial attachment or on-the-job training (OJT) program for instructors or trainers is also helpful. This programme will expose and provide the trainers with some new experience in the actual workplace environment.

\section{References}

Cort, et al. (2004). PROFF- Professionalisation of VET teachers for the future. CEDEFOP Panorama series; 104.Luxembourg.

Deissinger, T. and Hellwig, S. (2005). "Apprenticeships in Germany: modernizing the Dual System" Education + Training. Vol. 47, No. 4/5, 2005, pp 312-324.

Deissinger, T. (2001). "Vocational Training in Small Firms in Germany: the Contribution of the Craft Sector." Education + Training. Vol. 43, No. 8/9, 2001, pp 426-436.

Deissinger, T. (1997). “The German dual system - a model for Europe?” Education + Training. Vol. 39, No. 8, 1997, pp 297-302.

Gerds, P. and Hoepfner, D. (2003). Cornerstones for the development of National TVET-Teacher- QualificationStandards. Expert's Report Term 1. Ethio-German technical and Vocational Education and Training Program. BOBB, Berlin and Institute Technology and Education, University of Bremen, Germany.

Gibbons-Wood, D. and Lange, T. (2000). "Developing core skills - lessons from Germany and Sweden". Education + Training. Vol.42, No.1, 2000, pp.24-32

Harbison, F. and Myers, C.A. (1964). Education, manpower, and economic growth: Strategic of human resource development. New York: McGraw Hill.

Mamat, I. (2001). Effective Design and Successful Management and Training Eastview Publications Sdn Bhd Malaysia. (1991a). Malaysia: The Way Forward (Vision 2020). Kuala Lumpur: National Printing Department.

Malaysia. (1991b). Report of the Cabinet Committee on Training: Training for Industrial Development. Kuala Lumpur: Economic Planning Unit.

Malaysia. (2001). Eight Malaysia Plan 2001-2005. Putrajaya: Economic Planning Unit. 
Malaysia. (2006). Ninth Malaysia Plan 2006-2010. Putrajaya: Economic Planning Unit.

Mohamed, Z.B. and Othman A.B. (2006). "Lifelong Learning and Technical/Vocational Education and Training". Paper presented at the International Conference on Technical and Vocational Education and Training 2006 (ICTVET2006), organized by KUiTTHO in collaboration with UNESCO-UNEVOC in Johor Bahru on 22-23 August 2006.

Othman, A.B. and Morgan, W.J. (1998). "Employers and the State of Malaysia: Towards a Partnership in Human Resource Development?" Paper presented at the Malaysian Educational Research Association Inaugural Conference, 28-30 April 1998 in Penang, organized by Universiti Sains Malaysia.

Othman, A.B. (2003). The Role of the National Vocational Training Council in the Management of Vocational Training in Malaysia. A Critical Evaluation. Batu Pahat: Pusat Penerbit KUiTTHO.

Othman, A.B. (2005). "The National Dual Training System: An Alternative Mode of Training for Producing K-Workers in Malaysia”. In Aminah Ahmad (eds.), Human Resource Development: Practices and Directions for a Developed Malaysia. University Putra Malaysia Press Serdang. pp.3-8.

Othman, A.B. (2009). The implementation of skills training in Malaysia between 1970's and 1990's. Kuantan: Universiti Malaysia Pahang Publisher.

Pillai, P. ed. (1992). Training for Skilled Occupations: Involvement and Role of Industry. Goethe-Institute Kuala Lumpur.

Rahim, M.S, and Khadijal, A. (2010). "Social skills and social values training for future k-workers". Journal of European Industrial Training. Vol.34, No.3, 2010, pp.226-258.

Schmidt, H. and Alex, L. (1997). "The Dual System of Vocational Education and Training in Germany". In Roderick Millar and Jonathan Reuvid (eds.). Doing Business With Germany. London

Sulaiman, M. (2010). "Competencies required by the industry coaches to perform new tasks in implementation of the National Dual Training System". Unpublished PhD thesis, Universiti Tun Hussein Onn Malaysia in collaboration with University of Bremen Germany.

Woodhall, M. (1971). "Forecasting demand for qualified manpower: Some problems and difficulties". In Brian Holmes and David G. Scanlon (eds.). The World Yearbook of Education 1971/72: Higher Education in a changing world. London: Evans Brothers Limited, pp.216-226.

Table 1. Potential Tasks for Industry Personnel as Coaches

\begin{tabular}{|l|c|c|c|}
\hline & Executive level & Supervisory level & Senior Technician level \\
\hline Pedagogical skills & $\mathrm{X}$ & $\mathrm{X}$ & $\mathrm{X}$ \\
\hline Technical skills (experienced-based) & $\mathrm{X}$ & $\mathrm{X}$ & $\mathrm{X}$ \\
\hline Technical theoretical knowledge & & $\mathrm{X}$ & $\mathrm{X}$ \\
\hline Communication skills & & $\mathrm{X}$ & $\mathrm{X}$ \\
\hline Curriculum development & $\mathrm{X}$ & $\mathrm{X}$ & $\mathrm{X}$ \\
\hline Management of training activities & $\mathrm{X}$ & $\mathrm{X}$ & $\mathrm{X}$ \\
\hline Training evaluation \& assessment & $\mathrm{X}$ & $\mathrm{X}$ & $\mathrm{X}$ \\
\hline ICT skills & $\mathrm{X}$ & $\mathrm{X}$ & $\mathrm{X}$ \\
\hline Facilitation skills & $\mathrm{X}$ & $\mathrm{X}$ & \\
\hline Language competencies & & $\mathrm{X}$ & \\
\hline Diagnostic competence & & \\
\hline
\end{tabular}

Table 2. Potential Programs for Industry Personnel as Coaches

\begin{tabular}{|l|c|c|c|}
\hline & Executive level & Supervisory level & Senior Technician level \\
\hline Pedagogy training (didactic approach) & $\mathrm{X}$ & $\mathrm{X}$ & $\mathrm{X}$ \\
\hline Planning \& management of TVET & $\mathrm{X}$ & $\mathrm{X}$ & $\mathrm{X}$ \\
\hline Technology upgrading & & $\mathrm{X}$ & $\mathrm{X}$ \\
\hline Communication skills & & $\mathrm{X}$ & $\mathrm{X}$ \\
\hline Curriculum development & $\mathrm{X}$ & $\mathrm{X}$ & $\mathrm{X}$ \\
\hline Training evaluation \& assessment & $\mathrm{X}$ & $\mathrm{X}$ & $\mathrm{X}$ \\
\hline ICT enhancing program & $\mathrm{X}$ & $\mathrm{X}$ & $\mathrm{X}$ \\
\hline Facilitation training program & $\mathrm{X}$ & $\mathrm{X}$ & \\
\hline Language enhancing program & & & \\
\hline
\end{tabular}

